\title{
Storytelling: a Cultural Determinant of Health Among African American Cancer Patients
}

\author{
Jill B. Hamilton ${ }^{1}$
}

Published online: 23 February 2021

(C) American Association for Cancer Education 2021

African Americans continue to experience the highest overall cancer mortality rates, more advanced staged cancers [2], and higher levels of psychological distress from cancer than nonHispanic Whites [1]. African American patients and family members often attribute the root cause of their psychological distress to overwhelming anxieties and concerns that cancer will lead to suffering, death, and isolation for their family member diagnosed with cancer.

Older African Americans, in particular, have transmitted stories of "making it through" times of oppression and serious illness that incorporate their strong religious culture [5, 19]. Historically, stories communicated through religious songs that have memorized and transmitted orally was a strategy that has given African Americans deep meaning to their human existence [20]. Stories told through religious songs has also been a cultural strategy by which the African American slave communicated their fears to God and also a strategy to communicate encouragement to one another in their plight [19]. The spirituals, for example, permitted African slaves to maintain a positive sense of self (through a self-identity as a child of God), to cope with a life in servitude, and to express their belief in the promise of a future life that would be free of pain and suffering $[5,19]$.

African Americans have also incorporated Biblical text into their stories. Similar to religious songs, memorized biblical text was also used among the African American slave to express their belief systems as well as their perceived connectedness to God and to other individuals who were suffering and powerless [5, 19].

For example, biblical text frequently memorized and transmitted intergenerationally among African Americans to encourage individuals during adversity have frequently included

Jill B. Hamilton

jill.b.hamilton@emory.edu

1 Nell Hodgson Woodruff School of Nursing, Emory University, 1520 Clifton Rd, Atlanta, GA 30322, USA stories where God led the Israelites from Egyptian bondage, Daniel delivered from the lions' den, the Hebrew children's escape from the fiery furnace, and Joshua's conquest with the Battle of Jericho [5]. These stories grounded in biblical text were used among the African American slaves to communicate their existence as human beings and to express their belief in God's promise of deliverance from their suffering [5].

Currently, stories grounded in the strong religious and spiritual culture of African Americans continue to be a significant strategy to manage stressful life events among African Americans when confronting life-threatening illnesses such as cancer. During stressful situations such as uncertainties during treatment, unsupportive social interactions, and fears of recurrence, stories communicated via religious songs are sources of comfort and strength, enabling individuals to persevere and remain optimistic [8]. Supportive messages transmitted via religious songs and biblical text to overcome psychological distress are commonly and notably interwoven into the culture of African Americans [12, 19]. And, just as with their ancestors of African Americans, stories are used to share the belief of a sacred being who has the ability to protect, heal, and deliver them from the evils and sufferings of their worldly existence [5]. Moreover, stories are used to encourage a positive sense of self, to express a belief and faith in overcoming stressful life situations [5, 20], and to promote social relationships among naturally occurring family networks [9]. Despite this strong cultural heritage of storytelling through religious song narrative and impact on health and well-being, researchers and educators have yet to fully embrace and incorporate this meaningful strategy into the supportive care of African American cancer patients and their family members.

Interventions that are grounded in storytelling are emerging as a beneficial method for improving health outcomes among racial/ethnic minority groups as well as those with cancer [11, $13,16]$. Additionally, populations with low literacy skills who may prefer methods of orality to gain and/or regain their voices due to difficult circumstances may find storytelling beneficial [15]. In research among African American adult 
populations, storytelling interventions have resulted in increased health-promoting behaviors such as adherence to follow-up care and quality of life among breast cancer patients [6], increasing self-care among diabetic patients [7], and improvements to blood pressure [10]. In a review of these storytelling interventions, the content generally focuses on information for self-management of diabetes [21], for controlling high blood pressure [3,10,17], and cessation of smoking [4]. Culturally relevant storytelling interventions have also been designed to promote cancer screening and incorporated spirituality; however, whether these stories have incorporated religious songs and biblical text is not clear [18]. Storytelling interventions that incorporate culture, specifically dimensions of spirituality as simply as an add-on to other content for health promotion may not have lasting effects [14].

The incorporation of stories along with religious songs and biblical text might be of benefit to African American cancer populations and their family members in several ways. In terms of cancer education implications, healthcare practitioners might encourage the cancer patient to talk about their favorite religious song or biblical text and spiritual ways of coping during health assessments as a way to initiate conversations related to psychological distress levels. Secondly, healthcare practitioners might encourage the African American cancer patient experiencing high levels of psychological distress to recall a favorite religious song or biblical text and discuss with them ways in which the song or text might be a coping strategy and source of hope, comfort, and encouragement. Finally, healthcare practitioners might incorporate the cultural tradition of stories through religious songs and biblical text in programs designed to teach meditation skills. Mindfulness-based therapies that integrate the recall of a favorite religious song or biblical text would likely enhance the acceptability and participation in these and other cancer support programs.

The theme for this years' International Cancer Education Conference (ICEC) is Integrating Culture, Spirituality, and Social Support into Cancer Education to Improve Health Equity. The goals of this conference are focused on evidence-based practices and on new and creative models of cancer care that support best practice and facilitate interdisciplinary research and educational collaborations on the national and international levels. For this conference, we broadly think of culture as a social determinant of health that considers customary beliefs, social norms, attitudes, values, and practices in a given place and time. More specifically, scholarship and practice related to culture might focus on a cancer populations' shared language, religion, cuisine, social habits, music and arts and the ways in which this social determinant influences optimal cancer care. Together, the American Association for Cancer Education (AACE), the Cancer Patient Education Network (CPEN), and the European Association for Cancer Education (EACE) aim to create an atmosphere to use critical skills, ask questions, evaluate evidence, and engage in interesting and difficult conversations.

We hope to see you in person or virtually for our 2021 ICEC Conference.

\section{References}

1. Alcala HE (2014) Differential mental health impact of cancer across racial/ethnic groups: findings from a population-based study in California. BMC Public Health 14:930. https://doi.org/10.1186/ 1471-2458-14-930

2. American Cancer Society (2019) Cancer facts \& figures for African Americans 2019-2021. Retrieved from Atlanta

3. Ashton CM, Houston TK, Williams JH, Larkin D, Trobaugh J, Crenshaw K, Wray NP (2010) A stories-based interactive DVD intended to help people with hypertension achieve blood pressure control through improved communication with their doctors. Patient Educ Couns 79(2):245-250. https://doi.org/10.1016/j.pec. 2009.09.021

4. Cherrington A, Williams JH, Foster PP, Coley HL, Kohler C, Allison JJ, Kiefe CI, Volkman JE, Houston TK (2015) Narratives to enhance smoking cessation interventions among AfricanAmerican smokers, the ACCE project. BMC Res Notes 8:567. https://doi.org/10.1186/s13104-015-1513-1

5. Cone JH (2002) God of the oppressed. Orbits Books, Maryknoll

6. Davis C, Darby K, Moore M, Cadet T, Brown G (2017) Breast care screening for underserved African American women: communitybased participatory approach. J Psychosoc Oncol 35(1):90-105. https://doi.org/10.1080/07347332.2016.1217965

7. Goddu AP, Raffel KE, Peek ME (2015) A story of change: The influence of narrative on African-Americans with diabetes. Patient Educ Couns. 98:1017-1024. https://doi.org/10.1016/j.pec.2015.03. 022

8. Hamilton JB, Sandelowski M, Moore AD, Agarwal M, Koenig HG (2013) "You need a song to bring you through": the use of religious songs to manage stressful life events. Gerontologist 53(1):26-38. https://doi.org/10.1093/geront/gns064

9. Hamilton JB, Worthy VC, Moore AD, Best NC, Stewart JM, Song MK (2015) Messages of hope: helping family members to overcome fears and fatalistic attitudes toward cancer. J Cancer Educ. 32: 190-197. https://doi.org/10.1007/s13187-015-0895-z

10. Houston TK, Allison JJ, Sussman M, Horn W, Holt CL, Trobaugh J, Salas M, Pisu M, Cuffee YL, Larkin D, Person SD, Barton B, Kiefe CI, Hullett S (2011a) Culturally appropriate storytelling to improve blood pressure: a randomized trial. Ann Intern Med 154(2):77-84. https://doi.org/10.7326/0003-4819-154-2201101180-00004

11. Houston TK, Cherrington A, Coley HL, Robinson KM, Trobaugh JA, Williams JH, Foster PH, Ford DE, Gerber BS, Shewchuk RM, Allison JJ (2011b) The art and science of patient storytellingharnessing narrative communication for behavioral interventions: the ACCE project. J Health Commun 16(7):686-697. https://doi. org $/ 10.1080 / 10810730.2011 .551997$

12. Jones AC (1993) Wade in the water. The wisdom of the spirituals. Orbis Books, Maryknoll

13. Kreuter MW, Holmes K, Alcaraz K, Kalesan B, Rath S, Richert M, McQueen A, Caito N, Robinson L, Clark EM (2010) Comparing narrative and informational videos to increase mammography in low-income African American women. Patient Educ Couns 81(Suppl):S6-S14. https://doi.org/10.1016/j.pec.2010.09.008 
14. Kruizinga R, Hartog ID, Jacobs M, Daams JG, Scherer-Rath M, Schilderman JB et al (2016) The effect of spiritual interventions addressing existential themes using a narrative approach on quality of life of cancer patients: a systematic review and meta-analysis. Psychooncology 25(3):253-265. https://doi.org/10.1002/pon.3910

15. Larkey LK, Gonzalez J (2007) Storytelling for promoting colorectal cancer prevention and early detection among Latinos. Patient Educ Couns 67(3):272-278. https://doi.org/10.1016/j.pec.2007.04.003

16. Larkey LK, Lopez AM, Minnal A, Gonzalez J (2009) Storytelling for promoting colorectal cancer screening among underserved Latina women: a randomized pilot study. Cancer Control 16(1): 79-87. https://doi.org/10.1177/107327480901600112

17. Myers KR, Green MJ (2011) Storytelling: a novel intervention for hypertension. Ann Intern Med 154(2):129-130. https://doi.org/10. 7326/0003-4819-154-2-201101180-00013

18. Pérez M, Sefko JA, Ksiazek D, Golla B, Casey C, Margenthaler JA, Colditz G, Kreuter MW, Jeffe DB (2014) A novel intervention using interactive technology and personal narratives to reduce cancer disparities: African American breast cancer survivor stories. J Cancer Surviv 8(1):21-30. https://doi.org/10.1007/s11764-0130308-4

19. Raboteau AJ (1978) Slave religion. The "invisible institution" in the Antebellum South. Oxford University Press, New York

20. Raboteau AJ (2001) Canaan land. Oxford University Press, New York

21. Williams IC, Utz SW, Hinton I, Yan G, Jones R, Reid K (2014) Enhancing diabetes self-care among rural African Americans with diabetes: results of a two-year culturally tailored intervention. Diabetes Educ 40(2):231-239. https://doi.org/10.1177/ 0145721713520570

Publisher's Note Springer Nature remains neutral with regard to jurisdictional claims in published maps and institutional affiliations. 